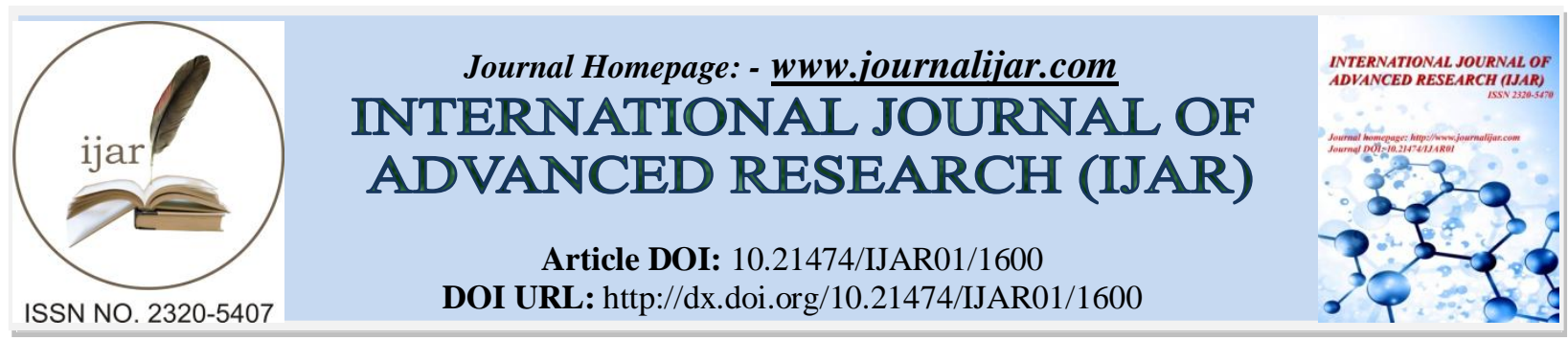

RESEARCH ARTICLE

\title{
ADVERSE EFFECTS OF TEA METABOLITES EXTRACTED DURING INDIAN HOUSEHOLD TEA PREPARATIONS ON DIGESTIVE ENZYMES AND IRON
}

\author{
Amitava Chatterjee ${ }^{*}$, Trina Das ${ }^{2}$, Ankita Basu ${ }^{2}$, Kamala Adak ${ }^{2}$, Swati Banerjee ${ }^{2}$ and Sumana Ghosh ${ }^{3}$. \\ 1. WBPHL, Dept. of Health \& Family Welfare, Govt. of West Bengal, West Bengal, India. \\ 2. Dept. of Home Science, University of Calcutta, India. \\ 3. Dept. of Chemistry, HMM College for Women, Dakshineswar, Kolkata, West Bengal, India.
}

\section{Manuscript Info}

\section{Manuscript History}

Received: 12 July 2016

Final Accepted: 19 August 2016

Published: September 2016

\section{Key words:-}

Household tea preparation, Secondary metabolites, enzymatic inhibition, Iron Chelation, Antidiabetic, Antiobesitic

\section{Abstract}

The study encompasses secondary metabolites and antioxidant potential estimation of green \& black tea during infusions under Indian household tea making processes. Tea infusions for $5,10 \& 15$ minutes in controlled (at $60,80 \& 100^{\circ} \mathrm{C}$ temperature) and uncontrolled environment (normal household preparation) were studied. Controlled infusions revealed optimised extraction conditions of each metabolite and served as the platform, based on which, normal household process was compared. Study suggests effective \& maximal utilization of metabolites for minimizing nutrient loss by correlating inhibitory roles of total polyphenols and total tannins with the digestive enzymes and iron and calculated the volume of tea required for certain $\%$ of enzymatic \& iron inhibitions. Green tea is more strong non-haem iron inhibitor (3.7- 4.6 times stronger than black tea) due to more total tannins and the volume of green tea required is almost half (48-55\% lesser) than that of black variety to have same enzymatic inhibition $\%$ (due to more available polyphenols), thus making it almost twice (1.82-2.07 times than black) as effective as black tea to act as antidiabetic and antiobesitic agents by their inhibitory actions upon $\alpha$-amylase \& lipase respectively. Drinking of green tea may not be suitable for the malnourished population, especially, in the Indian subcontinent due to higher available polyphenols \& tannins possessing adverse effects on digestive enzymes \& iron.

Copy Right, IJAR, 2016,. All rights reserved.

\section{Introduction:-}

\section{The context}

Tea chemistry is complex. On the bush, tea leaves contain thousands of chemical compounds. When they are processed, these compounds break down, form complexes and form new compounds. Many tea chemicals have been categorized into broad groups and collectively we have some ideas of their fate what happens to these groups during processing and what flavours and aromas they are responsible for. Plant leaves are made up of mostly water, and when they are removed from the plant they begin to wilt and lose water. Black tea represents approximately $72 \%$ of total consumed tea in the world, whereas green tea accounts for approximately $26 \%$. Recent interest in the health 
aspects associated with consumption of tea beverages has grown within the scientific community and has generated much excitement about tea polyphenols.

Brewing techniques vary widely according to cultural customs around the world (Wooward, 1980). Estimation of secondary metabolites intake from tea is subject to considerable variation (Stavric et al., 1988). There is little published information on estimation of secondary metabolites under household conditions, but estimation of metabolites contents \& antioxidant property of brewed tea with controlled time and temperature prompted the Working Group to compare the percentage change of metabolites contents \& antioxidant property of Darjeeling Tea (Green \& Black) during normal household tea making time and temperature (Temp uncon, Time ${ }_{\text {var }}$ ) with those of controlled conditions (Bunker et al., 1979).

In recent years there has been more and more research on the effect of consumer preparation on composition and activity of tea infusions (Lakenbrink et al., 2000, Su et al., 2006, Kyle et al., 2007, Molan et al., 2009).

The extraction temperature, extraction time, water quality and water-to-tea ratio, tea particle size, extraction $\mathrm{pH}$, and the number of extractions are all important factors which directly affected the quantity of the extracted antioxidants (Vuong et al., 2011). A few evidences have been found from some of the few research work. Such as in the case of green tea it was reported that- the higher temperature of brewing, the higher the reducing power of the infusion (Molan et al., 2009). Similarly, for black tea, the longer the time of brewing, the higher the antioxidant activity as well as the total phenolic and catechin contents (Kyle et al., 2007).

A tea drinker typically consumes 180 to $240 \mathrm{mg}$ of polyphenols from a strong cup of tea . Recent interest in the health aspects associated with consumption of tea beverages has grown within the scientific community and has generated much excitement about tea polyphenols.

\section{The genus Camellia:-}

The genus Camellia comprises evergreen shrubs which, in commercial cultivation, are maintained as a low bush in continuous vegetative growth. The genus contains a large number (Ca. 82) of species, but only the 'tea Camellia', Camellia sinensis is grown commercially. Other species, especially, Cam. irrawadiensis and Cam. taliensis are of importance as a source of genetic material (Varnam et al., 1994).

Although the length of time for steeping and the amount of water in which the leaves are steeped can vary widely, these factors generally control the amount of solids extracted, and to a lesser extent influence the composition. A typical brew of one tea bag in one cup of water produces a solution of $0.35 \% \mathrm{wt} / \mathrm{wt}$ solids, and from this value the dose expected from consumption of one cup of tea can be calculated. This is typically how tea phytochemicals are consumed (Matthew et al., 1997).

Darjeeling Tea:- Darjeeling, on the Southern slopes of the Himalayas in north east India. Darjeeling teas are cultivated at splendid altitudes of 800-2000 meters and it is the highest tea gardens. The region has just the right climatic conditions for cultivating fine tea bushes (http://www.teagschwendner.com/US/en/Tea_Growing_Regions. TG).

\section{Polyphenols \& Flavonoids Present In Tea Leaves:- \\ Polyphenols:-}

Polyphenols refers to a categorization of compounds composed of many phenolic groups with potent antioxidant properties (believed to be greater than even vitamin C). They give tea its bitter flavour. Because green tea leaves are young and have not been oxidized, green tea has up to 40 percent polyphenols, while black tea contains only about 10 percent. These compounds are plant metabolites produced as a defence against insects and other animals. They are derived from amino acids via sunlight and therefore tea grown in the shade has a smaller concentration of polyphenols and a higher concentration of amino acids.

\section{Flavonoids:-}

Within the flavonoid group, flavanols (also known as flavan-3-ols) are the most prevalent. Flavanols are also referred to as tannins, and during oxidation are converted to theaflavins and thearubigins - the compounds responsible for the dark colour and robust flavours notably present in black teas. Tea flavanols are sometimes 
collectively referred to as catechins. Besides flavanols, tea flavonoids also include flavonols, flavones, isoflavones, and anthocyanins; all of which contribute to the colour of a tea's infusion and its taste.

Black tea is produced by the full oxidation of tea leaves, which are then dried. Compounds from the flavonoids family called catechins make up $27 \%$ of the composition of unoxidised green tea; due to the oxidation process, this is reduced in black tea to around $4 \%$. The oxidation products of catechins in black tea are polyphenols, which influence both its colour and flavour.

\section{Proteins, Carbohydrates, Lipids and Iron Binding Action of Tea Metabolites:- Action on Proteins, Carbohydrates, Lipids:-}

Tea Polyphenols have been observed to have a strong precipitating effect on proteins, denaturing and reducing enzymatic activity (Sekia et al., 1984; Ozawa et al., 1987).

Immobilized polyphenols bind proteins reversibly, with restoration of enzyme activity after elution (Oh et al., 1980).

Dissolved ash metals such as hard water calcium may influence complexation, as in the case of tea scum formation (Spiro et al., 1996a; Spiro et al., 1996b). Green tea polyphenols have been shown to be more effective than traditional antioxidants such as BHA, BHT, ascorbic acid, and vitamin E (Tanizawa et al., 1984; Namiki et al., 1986; Zhao et al., 1989).

Although it is commonly stated that there are no tannins (meaning hydrolyzable tannins such as pentagalloylglucose) in tea, this statement is not strictly true. In addition to the gallic acid esters of the catechins and their oxidation products (which can be hydrolyzed to produce gallic acid readily and precipitate proteins), there is also a small quantity of hydrolyzable tannin (Nonaka et al., 1983; Yoshizawa et al., 1987; Hatano et al., 1989; Han et al., 1997).

\section{Experimental:-}

\section{Materials:-}

Folin-ciacalteu reagent (Spectrochem, 2(N), Batch No:2784208), Sodium Carbonate (Spectrochem, 99.5\%, Batch No:327555), Methanol (Merck, 99.8\%), Butylated hydroxyl toluene (Merck, 99\%, Batch No: 61774805001730), Tannic Acid (Merck, 99\%), Potassium Acetate (Merck, 99\%, Batch No: 61792805001730), Aluminium chloride (Merck, 98\%, Batch No: 380108302501730), Quercetin (SRL, 99\%, Batch No: T836708), Diphenylpicrylhydrazyl (Sigma Aldrich), Gallic Acid (CHD, 99\%, Batch No-050711).

Instruments: Spectrophotometer (Unicam 300 from Thermospectronics), Heating mantle, Conical flask, beaker, Micro pipette, Measuring cylinder.

\section{The Methodology:-}

\section{Sample preparation:-}

The tea leaves were from the gardens of Jungpana tea estate, Darjeeling.

The sample is stored in airtight container to prevent moisture gain.

For preparing samples, $0.5 \mathrm{gm}$ tea leaves was added to $50 \mathrm{ml}$ distilled water. Infusion was made at $60,80 \& 100^{\circ} \mathrm{C}$ for $5,10 \& 15 \mathrm{~min}$ (for each temperature condition). This solution* remained the sample for performing the experiments.

Another sample was prepared with same amount of tea leaves with respect to only the infusion time (water boiled at $100^{\circ} \mathrm{C}$, removed from heat source and tea leaves were infused) i.e. household tea making process.

\section{Moisture content of tea leaves:-}

Tea leaves were analysed for the moisture (dried in hot-air oven at $103-105^{\circ} \mathrm{C}$ for two hours and constant weight was noted) content to get the dry weight of samples.

\section{Method of Determination of Total Phenolic Compounds (TPC):-}

$0.1 \mathrm{ml}$ of sample solution* was taken into a test tube and $1 \mathrm{ml}$ (10 fold diluted) Folinciacalteu reagent, $0.8 \mathrm{ml} 2 \%$ $\mathrm{Na}_{2} \mathrm{CO}_{3}$ were added to it and the volume is made upto $10 \mathrm{ml}$ (volumetric flask) with distilled water. Absorbance of the solution was measured at $740 \mathrm{~nm}$ wavelength ( $\lambda_{\max }$ of gallic acid) (Agbor et al., 2014) against a standard 
calibration curve. Gallic acid was used as a reference standard and the calibration curve is prepared in the range of 20 to $100 \mu \mathrm{g}$ using $20,40,60,80,100 \mu \mathrm{g}$ as standard concentrations.

\section{Method of Determination of Total Tannin Content (TTC):-}

$0.1 \mathrm{ml}$ sample* was taken in a test tube and $7.5 \mathrm{ml}$ of water, $0.5 \mathrm{ml}$ of Folinciacalteu reagent and $1 \mathrm{ml}$ of $35 \%$ $\mathrm{Na}_{2} \mathrm{CO}_{3}$ solution was added to it. Then the volume was made upto $10 \mathrm{ml}$ (volumetric flask) by using distilled water and shaken well. The test tubes were incubated for $30 \mathrm{~min}$ at room temperature and absorbance was measured at 700 $\mathrm{nm}$ wavelength $\left(\lambda_{\max }\right.$ of tannic acid) (Agbor et al., 2014) against a standard calibration curve. Tannic acid was used as a standard and the calibration curve was prepared in the range of $20 \mu \mathrm{g}-100 \mu \mathrm{g}$ using $20,40,60,80,100 \mu \mathrm{g}$ as the standard concentrations.

\section{Method of Determination of Total Flavonoid Content (TFC):}

$1.9 \mathrm{ml}$ of methanol was added to $0.1 \mathrm{ml}$ of sample solution* (taken in a test tube). $0.1 \mathrm{ml} 10 \% \mathrm{AlCl}_{3}$ solution and 0.1 $\mathrm{ml}$ of $1 \mathrm{M} \mathrm{CH}_{3} \mathrm{COOK}$ were added to it successively and volume was made upto $5 \mathrm{ml}$ (volumetric flask) with distilled water. The solution was kept at room temperature for $30 \mathrm{~min}$. Absorbance of the solution was measured at $415 \mathrm{~nm}$ wavelength ( $\lambda_{\max }$ of quercetine) (Hassan et al., 2013) against a standard calibration curve. Quercetine was used as standard reference material and the calibration curve was prepared in the range of $20 \mu \mathrm{g}-100 \mu \mathrm{g}$ using 20, 40, 60, $80,100 \mu \mathrm{g}$ as the standard concentrations.

\section{Method of Determination of DPPH Free Radical Scavenging Activity:-}

5 different concentrations $(10,25,50,100,150 \mu \mathrm{g})$ of sample* were taken in test tubes. The volume was made upto $1 \mathrm{ml}$ by using $80 \%$ methanol. To each sample $3 \mathrm{ml}$ of DPPH reagent was added. The solutions were incubated in dark for $30 \mathrm{~min}$ and absorbance was taken at $517 \mathrm{~nm}$ wavelength against a standard calibration curve. During this whole process light was avoided as much as possible.

\section{Preparation of DPPH solution:-}

$0.004 \mathrm{gm}$ of DPPH was dissolved in $100 \mathrm{ml}$ of 80:20 methanol and the solution was kept in amber coloured bottle, avoiding light (Marsha et al., 2012).

\section{The look out:-}

The authors thus tried to estimate the secondary metabolites and antioxidant property of tea during infusions under normal household tea making certain inhibition percentage The values of controlled-temperature infusion served as the platform, based on which, the infusions of each process and to correlate the values of such metabolites with certain digestive enzymes and iron by suggesting the volume responsible for metabolite during normal household tea making process were compared.

\section{Results and discussion:-}

The outcome of work:

There are various ways by which consumers brew their tea. The main difference is in brewing time and temperature. Though there are some evidences that the antioxidant activity, polyphenols and tannin content increase with increase in brewing time and temperature, studying the influence of brewing time on polyphenols and antioxidants content of tea can contribute to the information on how to utilize the product effectively and maximally (Shonisani et al., 2010).

Changes in normal household infusion methods on the basis of the research would optimise the extraction and utilisation of metabolites to deliver optimal health benefit. During household tea making processes (Temp uncon, $_{\text {, }}$ Time $_{\text {var }}$ ), tea was infused for $5,10 \& 15$ minutes after water was boiled and removed from the heat source. Variations of metabolites and antioxidant properties have been observed, if we consider the values, as the infusion times have been increased. The $15 \mathrm{~min}$ time was chosen as the highest duration of infusion because in household tea makings, infusions are not done beyond that generally (Table1, Fig1).

The study comprised of tea infusion for 5, $10 \& 15$ minutes in controlled and uncontrolled environment - viz., infusion at $60,80 \& 100^{\circ} \mathrm{C}$ controlled temperature and tea infusion in water after it is boiled and removed from heat source. Each infused extract was filtered and the metabolites were estimated. 
The values of controlled-temperature infusion served as the platform, based on which, the infusions of each metabolite during normal household tea making process were compared.

Table1: Change of metabolites contents \& antioxidant property of Darjeeling Tea (Black \& Green) during normal household tea making time and temperature $\left(\mathbf{T e m p}_{\text {uncon }}\right.$ Time $\left._{\text {var }}\right)$

\begin{tabular}{|c|c|c|c|c|c|c|c|c|c|}
\hline \multirow{3}{*}{ Parameter } & \multirow{3}{*}{$\begin{array}{l}\text { Time } \\
\text { of } \\
\text { infusion } \\
\text { (min) }\end{array}$} & \multicolumn{6}{|c|}{ Infusion at Controlled Temperatures } & \multirow{2}{*}{\multicolumn{2}{|c|}{$\begin{array}{c}\text { Infusion at Uncontrolled } \\
\text { Temperatures } \\
\text { (Normal Household } \\
\text { Infusion) }\end{array}$}} \\
\hline & & \multicolumn{2}{|c|}{$60^{\circ} \mathrm{C}$} & \multicolumn{2}{|c|}{$80^{\circ} \mathrm{C}$} & \multicolumn{2}{|c|}{$100^{\circ} \mathrm{C}$} & & \\
\hline & & BLACK & GREEN & BLACK & GREEN & BLACK & GREEN & BLACK & GREEN \\
\hline \multirow{3}{*}{ 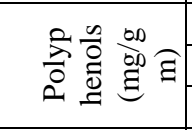 } & 5 & 150 & 357 & 195 & 518 & 300 & 609 & 100 & 182 \\
\hline & 10 & 275 & 539 & 310 & 637 & 410 & 910 & 115 & 203 \\
\hline & 15 & 155 & 448 & 280 & 602 & 395 & 686 & 125 & 259 \\
\hline \multirow{3}{*}{ 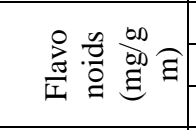 } & 5 & 50 & 5.0 & 60 & 50 & 80 & 6.0 & 60 & 60 \\
\hline & 10 & 5.5 & 5.5 & 8.0 & 6.0 & 11.0 & 7.0 & 7.0 & 7.0 \\
\hline & 15 & 7.0 & 6.0 & 9.0 & 7.0 & 12.0 & 8.0 & 8.0 & 7.5 \\
\hline \multirow{3}{*}{ 言气 气 $气$} & 5 & 125 & 357 & 205 & 532 & 315 & 665 & 85 & 392 \\
\hline & 10 & 230 & 609 & 330 & 686 & 445 & 777 & 110 & 420 \\
\hline & 15 & 200 & 455 & 280 & 637 & 425 & 728 & 120 & 448 \\
\hline \multirow{3}{*}{ 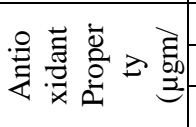 } & 5 & 50.06 & 52.11 & 44.97 & 49.69 & 47.79 & 41.14 & 47.07 & 45.44 \\
\hline & 10 & 49.16 & 47.99 & 43.03 & 36.68 & 40.81 & 39.29 & 37.23 & 42.45 \\
\hline & 15 & 42.34 & 47.05 & 24.88 & 34.89 & 40.13 & 36.94 & 34.83 & 38.52 \\
\hline
\end{tabular}

Experimental data depicted one interesting point that, the optimisation of each of polyphenols \& tannins (w.r.t. the two varieties of Darjeeling tea under study), occurred at the same time-temperature combination, viz., at $10 \mathrm{~min}-100^{\circ} \mathrm{C}$ infusion. Similarly, identical time-temperature combination of optimisation have been found out experimentally for the antioxidant property; viz., at $15 \mathrm{~min}-80^{\circ} \mathrm{C}$ infusion. On the other hand, w.r.t. flavonoids, the increasing trend continued and no optimisation could be recorded during the experimental period (15 minutes) of the two varieties of Darjeeling tea, pointing to the fact that higher temperature and higher time facilitated more and more extraction. For each variety, the lowest values for each of the metabolites were recorded experimentally during the lowest temperature-lowest time period of infusion combination.

During household tea making process, for each variety, the highest values for each of the metabolites was recorded experimentally during the highest temperature-highest time period of infusion combination. The household tea making, however, could not reveal the optimised value of each metabolite, pointing to the conclusion that, such uncontrolled temperature of infusion was not sufficient to maximise the extraction. The highest experimental values observed for each metabolite (during household extraction process) were lesser than the lowest values of corresponding metabolites (during controlled infusions) (Table1).

\section{Polyphenols:-}

The amount of polyphenols in green variety was much higher than that in the black; the result was in agreement with the chemistry of oxidation of tea leaves. In case of uncontrolled temperature, as the optimization of polyphenol release was not reached till $15 \mathrm{~min}$., so the upward trend continued. However, the rate of extraction varied in black $\&$ green teas; At lower time period of infusion $(5-10 \mathrm{~min})$, the black tea resulted in more polyphenolic extraction rate $(15.05 \%)$ than green tea $(11 \%)$; whereas, when the infusion time period was increased, the trend reversed (Black 8.7\%; Green 27\%) (Table1). The rate variation of extractions in black \& green tea may be explained thus: the unoxidised polyphenols require more time \& temperature to be available in the medium. 


\section{Flavonoids:-}

In normal household tea making process, the flavonoid content remained almost constant for both black \& green varieties of Darjeeling Tea (Table1) suggesting that there exist a lesser effect of time-temp variation upon this substance.

\section{Tannins:-}

The tannins content in black tea showed sharp upward trend $(29.41 \%)$ while moving from 5 to 10 min, but decreased drastically $(9.09 \%)$ in the case of 10 to $15 \mathrm{~min}$. duration. However, in case of green tea, the rate of extraction was almost same during the entire time period of experiment, i.e. while moving from 5 to $10(7.14 \%)$ and from 10 to $15 \mathrm{~min}$. (6.67\%). It may be concluded that at controlled heat, tannins may have been optimally released from the food mesh, with its optimum at around $10 \mathrm{~min}$. This result shows that lesser infusion time (510min) at uncontrolled temperature facilitated the maximum extraction of tannins (Table1). But, due to sustained heat beyond 10 min., tannins undergo polymerization, like the polyphenols leading to precipitation (Table1, Fig1).

\section{Antioxidant property:-}

Although the AO activity continued to increase during the experimentation period, the rate of change varied with time of infusion. While in case of black variety, a sharp higher increment has been observed while moving from 510min., the AO activity of the green variety followed a gradual upward trend as the infusion time was increased from 5 to 15 minutes.

In case of controlled infusions, the highest polyphenols and tannins content due to tea infusions were observed after $10 \mathrm{~min}$. infusion at $100^{\circ} \mathrm{C}(410 \& 445 \mathrm{mg} / \mathrm{gm}$ resp. $)$ and the lowest $(150 \& 125 \mathrm{mg} / \mathrm{gm} \mathrm{resp}$. $)$ was found in $5 \mathrm{~min}$. infusion at $60^{\circ} \mathrm{C}$. While, the lowest flavonoids content was observed in both $5 \mathrm{~min}$. infused sample at $60^{\circ} \mathrm{C}$ $(5 \mathrm{mg} / \mathrm{gm})$, the highest has been depicted by the $15 \mathrm{~min}$ infused tea at $100^{\circ} \mathrm{C}(12.0 \mathrm{mg} / \mathrm{gm})$. On the other hand, the highest $\mathrm{AO}$ activity $(24.88 \mu \mathrm{gm} / \mu \mathrm{l})$ due to tea infusions was observed after $15 \mathrm{~min}$. infusion at $80^{\circ} \mathrm{C}$ and the lowest $(50.06 \mu \mathrm{gm} / \mu \mathrm{l})$ in $5 \mathrm{~min}$. infusion at $60^{\circ} \mathrm{C}$.

TP plays an important role in protein precipitation and enzyme inhibition, through forming various complexes (Cartriona et al., 1988; Shi et al., 1994). It is known that most polyphenols, such as tannic acid, gallotannin, catechin and proanthocyanidin, can react with proteins. TP exhibits strong complexing abilities with enzymes. This should inevitably result in the change of enzyme molecular configuration and lead to the loss of catalytic activity. Many enzymes, such as tyrosinase, peroxidase, trypsin (Huang et al., 2004), decarboxylase (Bertoldi et al., 2001) squalene epoxidase (Abe et al., 2000) and ribonuclease (Ghosh et al., 2004) were found to be denatured by tea polyphenols. So it could be speculated that TP should bind and precipitate digestive enzymes and thereby reduce food digestibility. The EGCG, ECG and GCG account for more than $82 \%(\mathrm{w} / \mathrm{w})$ of the TP sample. It is therefore speculated that TP will take part in complexing reactions with protein and, to some extent, affect the activities of digestive enzymes.

Tea polyphenols showed the strongest inhibition of $\alpha$-amylase which has the highest molecular weight. In the presence of $0.05 \mathrm{mg} / \mathrm{ml}$ of TP, $\alpha$-amylase had the highest loss of enzyme activity and the residual activity is only $39 \%$ of the original. However, in comparison with pepsin, trypsin has a smaller molecular weight but a higher activity loss, suggesting that the inhibitory effects of tea polyphenols on enzymes do not completely depend on the molecular weight of the enzyme. The inhibitory effect of TP on lipase activity was also established (Nakai et al., 2005), where the effect of oolong tea polyphenols on pancreatic lipase was investigated.

The main mechanism of TP-protein (TP-enzyme) bonding is considered to be non-covalent interactions (Siebert $e t$ al., 1996; Dreosti et al., 2000). Tea polyphenols contain hydroxyl groups and galloyl groups in their molecular structure. The phenolic groups can form hydrogen bonds with the polar groups (amide, guanidine, peptide, amino and carboxyl groups) of protein. In other words, the composition and quantity of the polar groups in the enzyme protein will affect the formation and stability of hydrogen bonds between TP and the enzyme. Moreover, the galloyl groups in TP exhibit certain hydrophobicity (He, Shi, \& Yao, 2006). With the recognition that there are many hydrophobic amino acids present in enzyme protein, such as proline, phenylalanine and tyrosine, it could be considered that tea polyphenols should strongly bind enzymes through hydrophobic association. 
So, it could be concluded that tea polyphenols might act as an antinutritional factor, in terms of their inhibitory effects on digestive enzymes, which may be due to the cooperative effects of hydrophobic association and hydrogen bond formation between TP and the enzymes.

According to the studies by Siebert, Troukhanova, \& Lynn, 1996 \& Dreosti, it is clear that the TP-gelatin interaction occurs easily even in dilute solution. Further, with the increase of gelatin and TP concentrations, the bonding ability of TP with gelatin was strengthened.

Hence, based on the above studies of Siebert, Troukhanova, \& Lynn, 1996 \& Dreosti, 2000, there could be a reduction of the digestibilities of carbohydrates, proteins and lipids, whose hydrolyzation reactions in the gut are enzyme mediated. Hence, TP might act as an antinutritional factor, in terms of its potential to inhibit the activities of digestive enzymes.

The authors, therefore, tried to correlate the total polyphenols extracted during Indian household tea making processes with the percentage inhibition of Digestive Enzymes and calculated the volume of tea required to attain the prescribed dose of $0.05 \mathrm{mg} / \mathrm{ml}$ (Siebert, Troukhanova, \& Lynn, 1996; Dreosti, 2000) for the inhibition. The authors further, depicted the number of cups of tea required as per International Cup volumes.

From Table 2, it can be noticed that the volume of green tea required is almost half (48-55\% lesser) than that of black variety, for attaining the same percentage inhibition of digestive enzymes, due to the availability of more polyphenols. Thus, it can be said that green tea is almost twice (1.82-2.07 times) as effective as black tea to act as antidiabetic and antiobesitic agents by their inhibitory action upon $\alpha$-amylase \& lipase respectively. But, for the malnourished population, especially, in the Indian subcontinent, drinking of green tea may not be recommended.

\section{Action on Iron:-}

Iron is one of the most important essential trace elements for human life. Although quite abundant in the environment, iron deficiency still remains one of the most common deficiency syndromes in India, since the availability of iron for biological systems is limited. Therefore iron is spared within the human body, but there is no possibility of depleting surplus iron. Severe iron overload results in significant tissue damage, and even small amounts of excess iron may be harmful, leading to increased risk of cardiac infarction (Salonen et al., 1992).

Black tea in particular, a commonly used beverage, has been shown by Disler (1975) and others (Brune et al., 1989; de Alarcon et al., 1979; Morck et al., 1983) to reduce the uptake of iron from various sources of inorganic iron by about two thirds as compared with water intake (Tuntawiroon et al., 1991). Polyphenols are assumed to act by binding heavy metals in the gastrointestinal lumen. Table 1 shows that total tannin (TT) content in household-tea preparation varied with infusion time and the respective values in green tea are much more than that in the black variety. Further, from this data it can be suggested that that to obtain $66.8 \%$ Chelating Effect of Ferrous Ions by TT $(0.015 \mathrm{mg} / \mathrm{ml})$ (Gulcin et al., 2010), how much volume of tea is required (Table 3), as it is known that tannates have the ability to inhibit iron absorption (Gulcin et al., 2010). Table 3 depicts that the green tea happens to be a strong iron-chelating agent, ranging from 3.7- 4.6 times as potent iron binder as black tea due to the presence of higher amount of total tannins. Thus, the action of tea polyphenols (tannins) may be ascribed in two contradictory ways firstly, they may act as a beneficial agent to reduce iron overload in human systems by binding the non-haem iron (as has already been suggested by de Alarcon $e t$ al.); secondly, they may act as a inhibitory agent for the people suffering from anaemia (Zijp et al., 2000; Samman et al., 2001). 
Table2: \% Inhibition of Digestive Enzymes by Extracted Total Polyphenols (TP) due to Household Tea Preparations (Temp ${ }_{\text {uncon }}$, Time var $\left._{\text {va }}\right)$

\begin{tabular}{|c|c|c|c|c|c|c|c|c|c|c|}
\hline \multirow{2}{*}{\multicolumn{3}{|c|}{ Total Polyphenols (TP) }} & \multicolumn{5}{|c|}{ \% Inhibition of enzymes by TP $(0.05 \mathrm{mg} / \mathrm{ml})$} & \multicolumn{3}{|c|}{ No. of Cups of tea required } \\
\hline & & & \multicolumn{4}{|c|}{ Enzymes } & \multirow{3}{*}{$\begin{array}{l}\text { Vol. of } \\
\text { prepared tea } \\
\text { req to obtain } \\
\text { the conc. of } \\
0.05 \mathrm{mg} / \mathrm{ml}^{*} \\
(\mathrm{ml})\end{array}$} & \multirow{3}{*}{$\begin{array}{c}\text { Metric } \\
\text { Cup } \\
(250 \mathrm{ml})\end{array}$} & \multirow{3}{*}{$\begin{array}{c}\text { Imperial } \\
\text { Cup } \\
(284 \mathrm{ml})\end{array}$} & \multirow{3}{*}{$\begin{array}{c}\text { US } \\
\text { Customary } \\
\text { Cup } \\
(236.59 \mathrm{ml})\end{array}$} \\
\hline $\begin{array}{l}\text { Time of } \\
\text { infusion }\end{array}$ & Variety & $\begin{array}{c}\text { Conc. of } \\
\text { TP }\end{array}$ & $\begin{array}{c}\alpha- \\
\text { amylase }\end{array}$ & Pepsin & Trypsin & Lipase & & & & \\
\hline (min) & & $\begin{array}{l}\text { extracted } \\
\quad(\mathrm{ppm})\end{array}$ & \multicolumn{4}{|c|}{$\%$ inhibition } & & & & \\
\hline \multirow[b]{2}{*}{5} & Black & 100 & \multirow[b]{2}{*}{61} & \multirow[b]{2}{*}{32} & \multirow[b]{2}{*}{38} & \multirow[b]{2}{*}{54} & 500.00 & 2.0 & 1.8 & 2.1 \\
\hline & Green & 182 & & & & & 274.73 & 1.1 & 0.9 & 1.2 \\
\hline \multirow[b]{2}{*}{10} & Black & 115 & \multirow[b]{2}{*}{61} & \multirow[b]{2}{*}{32} & \multirow[b]{2}{*}{38} & \multirow[b]{2}{*}{54} & 434.78 & 1.7 & 1.5 & 1.8 \\
\hline & Green & 203 & & & & & 246.31 & 0.9 & 0.9 & 1.1 \\
\hline \multirow[b]{2}{*}{15} & Black & 125 & \multirow[b]{2}{*}{61} & \multirow[b]{2}{*}{32} & \multirow[b]{2}{*}{38} & \multirow[b]{2}{*}{54} & 400.00 & 1.6 & 1.4 & 1.7 \\
\hline & Green & 259 & & & & & 193.05 & 0.8 & 0.7 & 0.8 \\
\hline
\end{tabular}

Ref: *(Siebert, Troukhanova, \& Lynn, 1996; Dreosti, 2000)

Table 3:- Chelating Effect of Ferrous Ions $\left(\mathrm{Fe}^{2+}\right)$ by the Tannins $\left(\mathbf{T e m p}_{\mathbf{u n c o n}}, \mathbf{T i m e}_{\mathbf{v a r}}\right.$ )

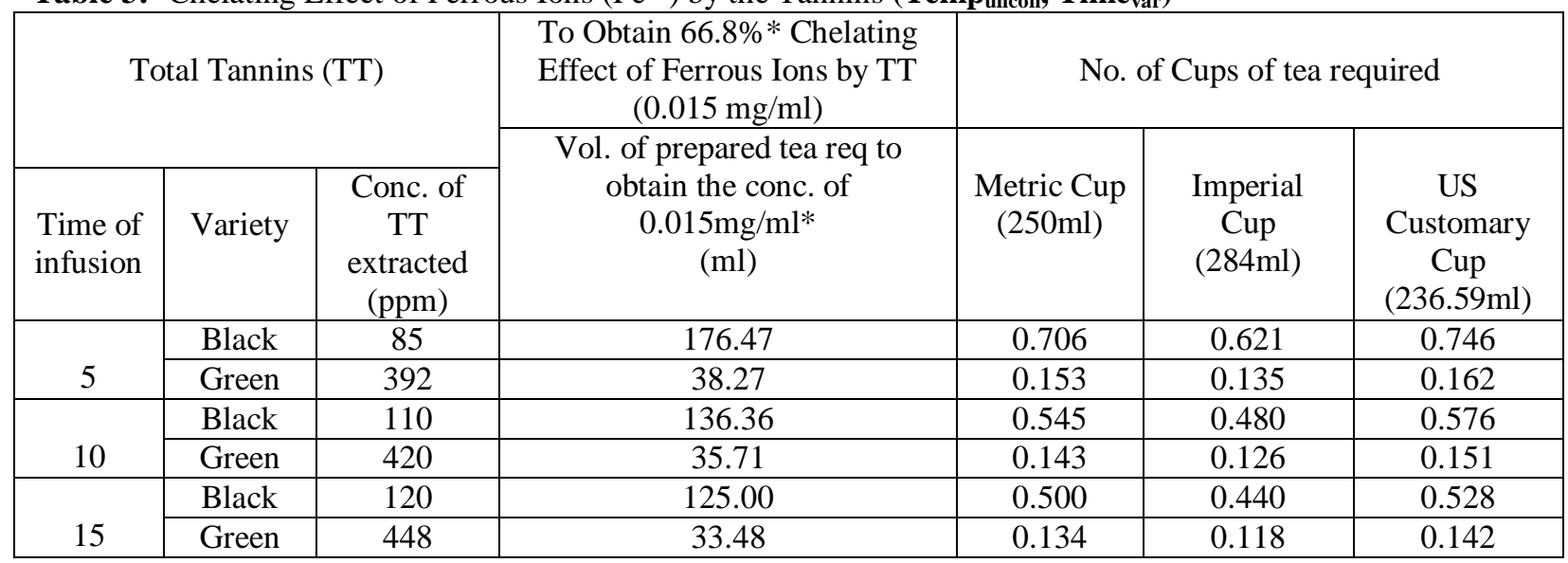

*ref: Ilhami Gulcin, Zubeyr Huyut, Mahfuz Elmastas, Hassan Y and Aboul-Enein;

Radical scavenging and antioxidant activity of tannic acid, Arabian Journal of Chemistry 3: 43-53(2010)
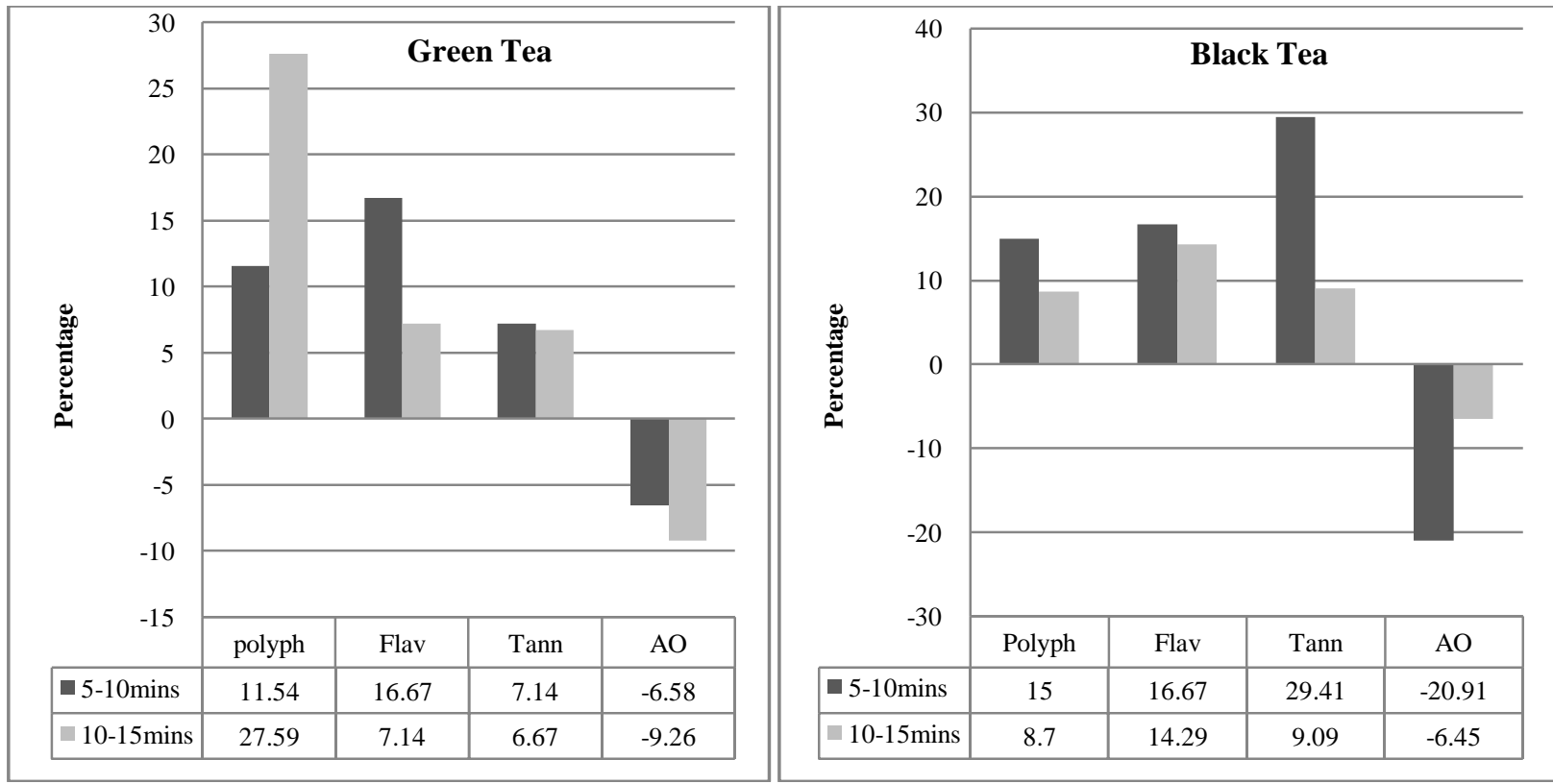

Fig 1:- Percentage Variations of metabolites and antioxidant property in household tea making processes. 


\section{Conclusions:-}

From the data presented it is evident that regular tea drinking with meals may exert a negative effect with respect to normal digestion processes as the tea metabolites possess some inhibitory properties against various digestive enzymes besides iron. Thus, tea - green tea in particular, may act as strong inhibitory agent against digestive enzymes and iron which might result in severe malnutrition and anaemia, especially in countries like India, where a good number of populations is still thriving below the poverty line. On the contrary, these negative effects of tea drinking with meals can be recommended as an additional therapeutic tool for the maintenance of normal body functions of persons suffering from diabetes, obesity and iron overload; as the inhibitory effects of tea metabolites might lessen the calorie intake along with iron. Therefore, drinking of tea, (green/black) may be said to be either beneficial or deleterious, when the physical conditions and nutritional status of the concerned individual is known. The study leaves a scope for further work using animal models to establish the proper enzymatic and iron inhibitions.

\section{References:-}

1. Abe, I., Seki, T., Umehara, K., Miyase, T., Noguchi, H., Sakakibara, J. and Ono, T. (2000); Green tea polyphenols: novel and potent inhibitors of squalene epoxidase, Biochem. Biophys. Res. Commun Vol 268: 767-771.

2. Agbor, G.A., Vinson, J.A. and Donnelly, P.E. (2014); Folin-Ciocalteau Reagent for Polyphenolic Assay, Int. J. Food Sci. Nutr. Die Vol 3(8): 147-156.

3. Bertoldi, M., Gonsalvi, M. and Voltattorni, C.B. (2001); Green tea polyphenols: novel irreversible inhibitors of dopa decarboxylase, Biochem. Biophys. Res. Commun Vol 284: 90-93.

4. Brune,M., Rossander, L. and Hallberg, L. (1989); Iron absorption and phenolic compounds: importance of different phenolic structures, Eur J Clin Nutr Vol 43:547-558.

5. Bunker, M.L. and McWiliams, M. (1979); Caffeine content of common beverages, J. Am. diet. Association Vol 74: 28-32.

6. Cartriona, M.S., Cai, Y., Russell, M. and Haslam, E. (1988); Polyphenol complexation-some thoughts and observations, Phytochemistry Vol 27: 2397-2409.

7. Changoiwala, S.M. (2006); Notes on the Biochemistry of Tea, http://cgadao.blogspot.in/2006_11_01archive.html

8. de Alarcon, P.A., Donovan, M.E., Forbes, G.B., Landaw, S.A. and Stockman, J.A. (1979); Iron absorption in the thalassemia syndromes and its inhibition by tea, N Engl J Med Vol 300:5-8.

9. Disler, P.B., Lynch, S.R., Charlton, R.W., Torrance, J.D., Bothwell, T.H., Walker, R.B. and Mayet, F. (1975); The effect of tea on iron absorption, Gut Vol 16(3): 193-200.

10. Dreosti, I.E. (2000); Antioxidant polyphenols in tea, cocoa, and wine. Nutrition Vol 16: 692-694.

11. Ghosh, K.S., Maiti, T.K. and Dasgupta, S. (2004); Green tea polyphenols as inhibitor of ribonuclease. Biochem. Biophys. Res. Commun Vol 325: 807-811.

12. Gulcin, I., Huyut, Z., Elmastas, M., Hassan, Y. and Aboul-Enein. (2010); Radical scavenging and antioxidant activity of tannic acid, Arabian Journal of Chemistry Vol 3:43-53.

13. Han, C. (1997); Screening of anticarcinogenic ingredients in tea polyphenols, Cancer Letters Vol 114: 153158.

14. Hassan, S.M., Al Aqil, A.A. and Attimarad M. (2013); Determination of crude saponin and total flavonoids content in guar meal, Advancement in Medicinal Plant Research Vol 1: 24-28.

15. Hatano, T., Edamatsu, R., Hiramatsu, M., MorI, A., Fujita, Y.T., Yoshida, T. and Okuda, T. (1989); Effects of the interaction of tannins with coexisting substances; Effect of tannins and related polyphenols on superoxide anion radical and on 1,1-diphenyl-2-picrylhydrazyl radical, Chem. Pharm Bull Vol 37: 2016.

16. Huang, H.H., Kwok, K.C. and Liang, H.H. (2004); Effect of tea polyphenols on the activities of soybean trypsin inhibitors and trypsin, J. Sci. Food Agric Vol 84: 121-126.

17. Kyle, J.A.M., Morris, P.C., Mcnill, G. and Duthie, G.G. (2007); Effects of infusion time and addition of milk on content and absorption of polyphenol from black tea, J. Agric. Food Chemistry Vol 55(12): 4889-4894.

18. Lakenbrink, C., Lapczynski, S., Maiwald, B. and Engelhardt, U.H. (2000); Flavonoids and other polyphenols in consumer brews of tea and other caffeinated beverages, J. Agric. Food Chemistry Vol 48: 2848-285.

19. Marsha, J.L. (2012); Protocol No. \& Title: 15.3b Natural Product Screening: Anti-oxidant Screen for Extracts, Version Date: 19October Version 1. 
20. Matthew E. H. and Douglas A. B. (1997); Chemical composition, an overview. In: Tea Chemistry, Critical Reviews in Plant Sciences 16(5):415-480.

21. Molan, A.L., Flanagan, J., Wei, W. and Moughan, P.J. (2009); Selenium-containing green tea has higher antioxidant and prebiotic activities than regular green tea, Food Chemistry Vol114: 829-835.

22. Morck,T.A., Lynch, S.R. and Cook, J.D. (1983); Inhibition of food iron absorption by coffee, Am J Clin Nutr Vol 37:416-420.

23. Nakai, M., Fukui, Y., Asami, S., Toyoda-Ono, Y., Iwashita, T., Shibata, H., Mitsunaga, T., Hashimoto, F. and Kiso, Y. (2005); Inhibitory effects of oolong tea polyphenols on pancreatic lipase in vitro, J. Agric Food Chem Vol 53: 4593-4598.

24. Namiki, M. and Ozake, M. (1986); Antioxidants/ Antimutagens in Foods, in Antimutagenesis and Anticarcinogenesis mechanisms', Basic Life Science, Plenum Press, New York, 131-142.

25. Negukhula Shonisani (2010); Effects of brewing temperature and duration on quality of black tea (Camellia Sinensis) and equal (50:50) combination of bush tea (Athrixia Phylicoides Dc.) and black tea. MiniDissertation for the degree of Master of Science in Agriculture (Horticulture)', Faculty of Science and Agriculture, University of Limpopo.

26. Nonaka, G., kawahara, O. and Nishioka, I. (1983); Tannins and related compounds. A new class of dimeric flavan-3-ol gallates, theasinensins A and B and proanthocyanidin gallates from green tea leaf, Chemical and Pharmaceutical Bulletin (Tokyo) Vol 31: 3906-3914.

27. Oh, H.I., Hoff, J.E., Armstrong, G.S. and Haff, L.A. (1980); Hydrophobic interaction of tannin-protein complexes, J. Agric. Food Chemistry Vol 28: 394-398.

28. Ozawa, T., Lilley, T.H. and Haslam, E. (1987); Polyphenol interactions: astringency and the loss of astringency in ripening fruit, Phytochemistry Vol 26: 2937-2942.

29. Salonen, J.T., Nyyssönen, K., Korpela, H., Tuomilehto, J., Seppänen, R. and Salonen, R. (1992); High stored iron levels are associated with excess risk of myocardial infarction in eastern Finnish men, Circulation Vol 86(3): 803-11.

30. Samman, S., Sandstrom, B., Toft, M.B., Bukhave, K., Jensen, M., Sorensen, S.S. and Hansen, M. (2001); Green tea or rosemary extract added to foods reduces nonheme-iron absorption, Am. J. Clin. Nutr Vol 73(3): 607-612.

31. Sekiya, J., Kajiwara, T., Monma, T. and Hatanaka, A. (1984); Interaction of tea catechins with proteins: formation of proteins precipitate, Agric. Biol. Chemistry Vol 48:1963-1967.

32. Shi, B., He, X.Q. and Haslam, E. (1994); Gelatin-polyphenol interaction. Journal of American Leather Chemists Association Vol 89: 98-104.

33. Siebert, K.J., Troukhanova, N.V. and Lynn, P.Y. (1996); Nature of polyphenolprotein interactions, J. Agric Food Chem Vol 44: 80-85.

34. Spiro, M. and Jaganyi, D. (1996); Kinetics and equilibria of tea infusion: The kinetics of the formation of tea scum, Food Chemistry Vol 49: 359-365.

35. Spiro, M. and Jaganyi, D. (1996); Kinetics and equilibria of tea infusion. Part 11. The kinetics of the formation of tea scum, Food Chemistry Vol 49: 359-365.

36. Stavric, B., Klassen, R., Watkinson, B., Karpinski, K., Stapley, R. And Fried, P. (1988); Variability in caffeine consumption from coffee and tea: possible significance for epidemiological studies, Food Chem. Toxic. Vol 26(2):11-18.

37. Su, X.G. and Duan, S. (2006); Effects of soaking condition on antioxidant property of Oolong Tea, Tea Chemistry-Tocklai, Tocklai Tea Research Association, N.D. Http://Www.Tocklai.Org/Activities/TeaChemistry.

38. Tanizawa, H., Toda, S., Sazuka, Y., Taniyama, T., Nayashi, T., Arichi, S. and Takino, Y. (1984); Natural antioxidants. Antioxidative components of tea leaf (Thea sinensis L.), Chemical and Pharmaceutical Bulletin (Tokyo) Vol 32: 2011-2014.

39. Tea_Growing_Regions. http://www.teagschwendner.com/US/en/TG

40. Tuntawiroon, M., Sritongkul, N., Brune, M., Rossander-Hultén, L., Pleehachinda, R., Suwanik, R. and Hallberg L. (1991); Dose-dependent inhibitory effect of phenolic compounds in foods on non haem iron absorption in men, Am J Clin Nutr Vol 53:554-557.

41. Varnam, A. and Sutherland, J.M. (1994); Beverages: technology, chemistry and microbiology, London: Chapman \& Hall, Ch 4, pp 128. 
42. Vuong, Q.V., Golding, J.B., Stathopoulos, C.E., Nguyen, M.H. and Roach, P.D. (2011); Optimizing condition for extraction of catechin from green tea using hot water, Vol 34(21): 3099-3106.

43. Wooward, N.H. (1980); 'Teas of the World', Collier MacMillan Canada Ltd., New York, pp. 184

44. Yoshizawa, S., Horiuchi, T., Fujiki, H. (1987); Antitumor promoting activity of (-)epigallocatechin gallate, main constituent of "tannin" in green tea, Phytother Re Vol 1: 44-47.

45. Zhao, B.L., Li, X.J., He, R.G., Cheng, S.J. and Xin, W.J. (1989); Scavenging effect of extracts of green tea and natural antioxidants on active oxygen radicals, Cell Biophys Vol 14(2): 175-85.

46. Zijp, I.M., Korver, O. and Tijburg, L.B.M. (2000); Effect of Tea and other dietary factors on iron absorption, Critical Reviews in Food Science and Nutrition Vol 40(5): 371-398. 